\title{
The Role of Perceived Risks on Millennials on Online Purchase Intention at Travel Agencies During the Covid-19 Pandemic
}

\author{
Carissa Lorens Marchia Raharja ${ }^{1}$ Aswin Dewanto Hadisumarto ${ }^{1 *}$ \\ ${ }^{1}$ Faculty of Economics and Business, Universitas Indonesia \\ *Corresponding author, Email: aswin.hade@gmail.com
}

\begin{abstract}
The increasing use of the internet has influenced the development of travel agents with the existence of online travel agents. The growth of the internet is also one of the triggers for millennials to travel. However, the Covid-19 pandemic makes millennials have to consider the risks in their purchase intentions at travel agents. This research wants to study how perceived risks affect online purchase intention of travel agencies during the Covid-19 pandemic. There are six perceptions of risk that are measured, namely, financial risk, product risk, risk, security, time risk, social risk, and psychological risk. The survey will be carried out by distributing questionnaires to 310 respondents who will focus on the millennial generation as respondents. The results showed that during a pandemic, the observed risk of perception had a negative effect on purchase intentions of online travel agents. Product risk, time risk and psychological risk are the three risks that have the highest negative influence on online purchase intentions during the Covid-19 pandemic. The results also show that the pandemic changes consumer behavior in seeing the risks they will face. By understanding the differences in risk perceptions, companies can reduce perceived risks that will have a negative impact on consumer purchase intentions.
\end{abstract}

Keywords: Perceived risks, Purchase intention, Millennials, Covid-19.

\section{INTRODUCTION}

The development of e-commerce continues to increase every year in Indonesia. The Internet users in Indonesia reached $64.8 \%$ in 2018 , while the previous year was $54.68 \%[1]$. In January 2020, the internet users in Indonesia is 175.4 Million People [2]. The internet users in Indonesia are dominated by 15-39 year olds and $94.4 \%$ of millennials in Indonesia are connected to the internet [3]. Millennials dominate compared to other generations and will be a demographic bonus, Millennials will become the backbone of the economy in Indonesia. The growth of millennials will have an impact on changing mindsets, social values, culture, and behavior [4]. The attitudes and behaviors of millennials will be heavily influenced by technology as well as the internet. The increase of internet in Indonesia also affects the development of travel agents with the presence of online travel agents [5]. The presence of ecommerce makes consumers can choose to buy products online or in stores [6]. This makes travel agents innovate in online form.

Online travel agent (OTA) currently not only offers flight tickets but also offers hotels, packages, tours, and others. Traveloka and Tiket.com, and become applications used to meet the needs in travel. With the presence of an online travel agent the public can adjust their time and desires during the holidays. The growth of e-commerce in tourism in 2019, showed that there was a growth of $15 \%$ compared to the previous year[2]. In addition, DailySocial

[7] in the Online Travel Agent 2018 survey stated that $71.44 \%$ of respondents have used online travel agents. This survey shows that people are now made easier to make purchases and compare the prices and services offered. The existence of the Covid-19 pandemic phenomenon makes it difficult for consumers to make choices in travel. Social restrictions require millennials not to travel. Vocation is the most desirable thing when the Covid-19 pandemic is over [8]. In this case consumers will consider the risks that will be faced when deciding to travel.

The perceived risk is the main concern of consumers who want to shop online. Privacy and security risks are the belief that consumer credit cards and personal information are vulnerable to thieves when shopping on the Internet[9]. The perceived risks are mainly related to the search and selection of information related to products by customers before they make a purchase decision [10]. Consumer purchasing intentions are an important factor to predict consumer behavior in measuring the influence of decision making under different circumstances. Perceived risks have been 
identified as a major determinant in consumer behavior [11].

This study wants to see how the perception of online risks in millennials will affect their purchasing intentions online, especially during the Covid-19 pandemic. The perceived risks can be seen when consumers face a product or service, they are uncertain because of some kind of difficulty that causes misery or imbalance [12]. The dimension of risk perception namely functional risk, financial risk, physical risk, and psychological risk has a negative influence on consumer purchasing intentions[13]. While the perceived risks in online purchases can be measured by finance, products, security, social, time, and phycholgical risk [ 10]. Buying intentions are often used as a measure to predict actual customer purchasing activities [10]. Thus, this research will test the role of risk perception for millennials towards the intention of online purchases in travel agents during the Covid-19 pandemic.

\section{LITERATURE REVIEW}

\section{Millennial}

Millennials were born in the range between 1980 to 2000 [14]\{15] [16]. However, there are a different opinion that millennials are a generation born in the range of 1982-2000[17] and millennials are defined as millennials with a group of people born from 1980 to $1995[18]$

\section{Perceived Risks}

The perception of risk is the expectation of losses [19]. The perception of risk relates to all sorts of possibilities or unforeseen events that may occur when a customer buys a product or service. Perceived risks is define as consumer confidence in the risks that negatively impact potential uncertainty in the purchasing situation

[20]. As a result, the risk of becoming higher will decrease the intention of purchasing customers [21]. The perception of risks in online activities can consist of financial risks, product risks, security risks, time risks, social risks, and psychological risks [10].

\section{Purchase Intention}

The intention of purchasing is the possibility of consumers in buying products based on the interaction between customer needs, attitudes and perceptions of products or brands [22]. The intention to buy can be considered as the interest of consumers to buy certain products [10].

\section{RESEARCH METHODS}

The frame of thought of this research can be seen in flow charts such as Figure 1.

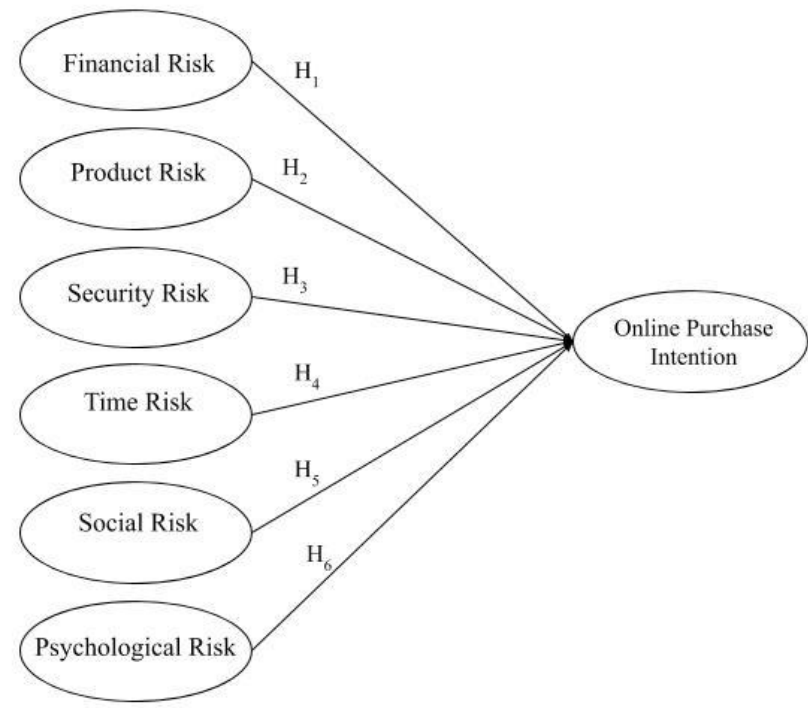

Figure 1. Research Framework Source: Ariffin et al., (2018)

Figure 1 is a research model built from previous research. A research by Ariffin[10] uses financial risks, product risks, security risks, time risks, social risks, and psychological risks in measuring online purchasing intentions. The results showed that there are only five factors that have a negative influence on consumers' online buying intentions, namely financial risks, security risks, product risks, time risks and psychological risks. Soo-Hyun Jun [23] in his research stated that financial risks, social risks, time risks, and psychological risks negatively affect purchasing intentions. In addition, Sujit Kumar Ray and Sangeeta Sahney [24] use five aspects of risk, namely financial risk, performance risk, psychological risk, social risk and physical risk. Simarpreet Kaur and Sangeeta Arora [25] in measuring consumer purchasing intentions using risks to performance, security, finance, time, social, and psychological. Muhammad Ashoer [26] used this research to examine the dimensions of risk perception that affects (financial, time, social, product, delivery, payment and privacy, and after-sales risk) of $\mathrm{s}$ commerce customers' purchasing intentions in Indonesia.

\section{Research Hypothesis}

H1 : Financial risk negatively affects the intention of online purchases.

H2 : Product risk negatively affects online purchasing intentions.

H3 : Security risks negatively affect the intention of online purchases.

H4: Time risk negatively affects online purchase intentions.

H5 : Social risk negatively affects the intention of online purchases. 
H6: Psychological risk negatively affects the intention of online purchases.

\section{Population and Sample}

The population in this study is a society that has the intention to use a Travel Agent. The method used in determining samples is purposive sampling method. The sample size used is 5-10 times the number of indicators. There are 27 indicators in this study and if multiplied by 5 then the number of samples used in this study is 135 respondents.

\section{Data Analysis Techniques}

Data collection in this study was conducted using questionnaires. The questionnaires and data collection will be distributed online through Google Form. All research instruments will be tested with validity and reliability test before the distribution of questionnaire.

\section{RESULTS AND DISCUSSIONS}

Total respondents in research are 310. Characteristics of respondents based on gender criteria in this study dominated by female respondents in 198 people with a percentage of 63.87 percent. Characteristics of respondents based on age criteria, respondents with an age range of 20 - 25 years dominated with a percentage of 50.7 percent, while the lowest percentage was owned by respondents with an age range of 36-40 years with a percentage of 11.9 percent. Based on the job criteria, private employees dominated the number of 183 respondents with a percentage of 59 percent. In the expenditure for the holidays / year respondents are dominated by 109 respondents with expenditures of Rp 5,000,001-10,000,000 per year. Furthermore, the frequency of travel agent usage / year is dominated by 162 respondents who use travel agents less than three times per year.

Table 1. Profile of respondents

\begin{tabular}{|l|l|l|l|}
\hline Item & Option & Frequency & $(\%)$ \\
\hline \multirow{3}{*}{ Gender } & Male & 112 & 36.13 \\
\cline { 2 - 4 } & Female & 198 & 63.87 \\
\hline \multirow{3}{*}{ Age } & $20-25$ & 157 & 50.7 \\
\cline { 2 - 4 } & $26-30$ & 70 & 22.6 \\
\cline { 2 - 4 } & $31-35$ & 46 & 14.8 \\
\cline { 2 - 4 } & $36-40$ & 37 & 11.9 \\
\hline \multirow{3}{*}{ Position } & Student & 63 & 20 \\
\cline { 2 - 4 } & Private employee & 183 & 59
\end{tabular}

2. Result
structures

\begin{tabular}{|c|c|c|c|c|}
\hline Variable & $\begin{array}{c}\text { Coefficien } \\
\mathbf{t} \\
\text { Regressio } \\
\mathbf{n}\end{array}$ & $\begin{array}{c}\text { T } \\
\text { value }\end{array}$ & Sig. & Notes \\
\hline $\begin{array}{lr}\text { Financial } & \begin{array}{r}\text { risks } \\
\text { online }\end{array} \\
\text { purchase } & \\
\text { intentions } & \\
\end{array}$ & $-0,111$ & 2,217 & $\begin{array}{c}0,02 \\
7\end{array}$ & $\begin{array}{c}\text { Negative } \\
\text { Effects }\end{array}$ \\
\hline $\begin{array}{l}\text { Product risk } \rightarrow \\
\text { online purchase } \\
\text { intentions }\end{array}$ & $-0,182$ & $\begin{array}{r}- \\
2,847\end{array}$ & $\begin{array}{c}0,00 \\
5\end{array}$ & $\begin{array}{l}\text { Negative } \\
\text { Effects }\end{array}$ \\
\hline $\begin{array}{lr}\begin{array}{lr}\text { Security } & \text { risks } \\
\rightarrow & \text { online }\end{array} \\
\text { purchase } & \\
\text { intentions } & \\
\end{array}$ & $-0,076$ & $\begin{array}{r}- \\
1,989\end{array}$ & $\begin{array}{c}0,04 \\
8\end{array}$ & $\begin{array}{c}\text { Negative } \\
\text { Effects }\end{array}$ \\
\hline
\end{tabular}

\begin{tabular}{|c|c|c|c|}
\hline & & & \\
\hline & Entreprenuer & 25 & 8 \\
\hline & Civil servant & 8 & 2.4 \\
\hline & House wife & 6 & 2.6 \\
\hline & Other & 25 & 8 \\
\hline Spending for & $<2.000 .000$ & 47 & 15.1 \\
\hline & $\begin{array}{l}2.000 .001- \\
5.000 .000\end{array}$ & 70 & 22.6 \\
\hline & $\begin{array}{l}5.000 .001- \\
10.000 .000\end{array}$ & 109 & 35.2 \\
\hline & $\begin{array}{l}10.000 .001- \\
15.000 .000\end{array}$ & 48 & 15.5 \\
\hline & $\begin{array}{l}15.000 .001- \\
20.000 .000\end{array}$ & 21 & 6.8 \\
\hline & $>20.000 .000$ & 15 & 4.8 \\
\hline Frequency of & $<3$ & 162 & 52.3 \\
\hline agent/year & $3-5$ & 109 & 35.2 \\
\hline & $6-10$ & 29 & 9.3 \\
\hline & $>10$ & 10 & 3.2 \\
\hline
\end{tabular}

Validity test results on all instruments in variable roles perceived risk in millennials against the intention of online purchases in travel agents during the Covid-19 pandemic has factor analysis and all instruments in this study are valid. Similarly, to reliability tests, the results showed that the entire Cronbach's Alpha value was over 0.6. Therefore, all variables are declared reliable and can be used to conduct research.

Table 2. Results of Multiple Regression Analysis 


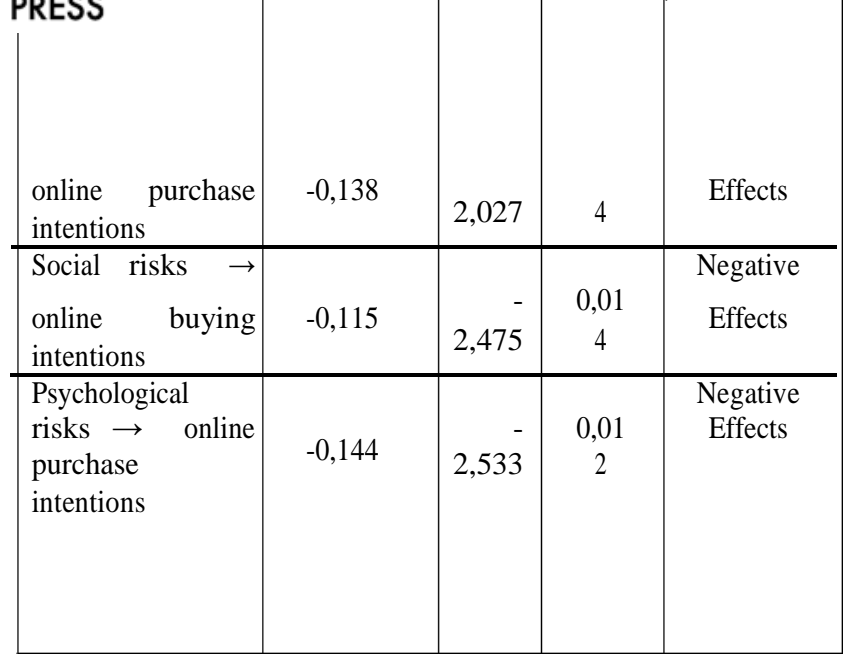

Multiple linear regression analysis to analyze the influence of financial risk, product risk, security risk, time risk, social risk, and psychological risk to online purchasing intentions can be seen in Table 2.

The results of the t-test calculation in Table 2 showed the coefficient of regression X1 or Financial risk to the intention of online purchase is -0.111 which is negative value with a significance rate of 0.027 less than 0.05. This indicates that financial risk has a significant negative effect on the intention of online purchases, then H1a is accepted.

The result of $t$ test calculation in Table 2 shows the value of $\mathrm{X} 2$ regression coefficient or Product risk to online purchase intention is -0.182 which is negative value with significance level of 0.005 less than 0.05 . This indicates that the risk of the product has a significant negative effect on the intention of online purchase, then $\mathrm{H} 2 \mathrm{a}$ is accepted.

The results of the t-test calculation in Table 2 showed the coefficient of X3 regression or Security risk to online purchase intention is -0.076 which is negative value with a significance level of 0.048 less than 0.05 . This indicates that the security risk has a significant negative effect on the intention of online purchases, hence H3a is accepted.

The result of $t$ test calculation in Table 2 shows the value of $\mathrm{X} 4$ regression coefficient or Time risk to online purchase intention is -0.138 which is negative value with significance level of 0.044 less than 0.05 . This indicates that the risk of time has a significant negative effect on the intention of online purchases, hence $\mathrm{H} 4 \mathrm{a}$ is accepted.

The results of the t-test calculation in Table 2 showed the value of the X5 regression coefficient or Social risk to the intention of online purchase is -0.115 which is negative value with a significance level of 0.014 less than 0.05 . This indicates that social risk has a significant negative effect on the intention of online purchases, hence H5a is accepted.

The results of the t-test calculation in Table 2 showed the coefficient of regression X6 or Psychological risk to the intention of online purchase is -0.144 which is negative value with a significance level of 0.012 less than 0.05 . This indicates that psychological risks have a significant negative effect on the intention of online purchases, hence $\mathrm{H} 6 \mathrm{a}$ is accepted.

Table 3. Coefficient of Determination and $F$ Test Results

\begin{tabular}{|c|c|c|c|}
\hline $\mathrm{R}$ & $\begin{array}{c}\mathrm{R} \\
\text { Square }\end{array}$ & $\begin{array}{c}\text { Adjusted } \\
\text { R Square }\end{array}$ & $\begin{array}{c}\text { F Value \& } \\
\text { Signification }\end{array}$ \\
\hline $0,607^{\mathrm{a}}$ & 0,368 & 0,356 & $\begin{array}{c}1,96463 \\
(0,000)\end{array}$ \\
\hline
\end{tabular}

Source: Processed data, 2020

The test result in Table 3 gives adjusted $\mathrm{R} 2$ result (adjusted determination coefficient) of 0.356 . This means that $35.6 \%$ variation in online purchase intentions can be significantly affected by variable online financial risks, online product risk, online security risk, online time risk, online social risk, and online psychological risk, while the remaining $64.4 \%$ is explained by other factors.

$F$ test results showed calculated $F$ values of 1,96463 with a significance of 0.000 which is less than $\alpha=0.05$, this means that the model used in this study are already worthy of the test. These results give the meaning of all independent variables capable of predicting or explaining the phenomenon of online purchasing intentions. This means that simultaneously financial risks, product risks, security risks, time risks, social risks, and psychological risks have a significant effect on the intentions of online purchases studied

\section{CONCLUSIONS}

Based on the results of anlysis, it can be concluded as follows.

1. The results showed that there are six risks that have a negative influence on the intention of online purchases. Online financial risks, online product risks, online security risks, online time risks, online social risks, and online psychological risks in this study had a negative influence on online purchasing intentions.

2. Product risk, time risk and psychological risk are the three risks that have the highest negative influence on online purchase intentions during the Covid-19 pandemic.

\section{SUGGESTIONS}

1. In online financial risk, the tendency to spend over budget becomes a higher value than other indicators. This suggests that to increase the intention of online purchases it is necessary to reduce the perception of risk from consumers going shopping more than when using online travel agents.

2. Based on the results of variable descriptions on online product risk, consumers have difficulty comparing product quality in online travel agents to 
indicators that have higher value than other indicators. This can make consumers undo their intention to make purchases in online travel agents. During Covid-19, consumers want quality.

3. At the risk of online security indicators consumers feel afraid if their personal information is owned by other online travel agents into a perception of online security risks that have a higher value than other indicators. Fear of the spread of personal information to other online travel agents will negatively affect the intention of the purchase. OTA here can ensure the security of the site that consumer personal information will not be owned or stolen by other OTAs

4. The results of the online time risk variable analysis in the questionnaire showed results that had a higher value than other indicators on customers' difficulty in finding the right product on an online travel agent. The time required in finding and choosing the right product makes the consumer undo his intention to make a purchase. OTA can personalize searches so that customers can more easily find the products they are looking for and the risk of time will decrease.

5. The result of analysis of online social risk variable description of products unknown to relatives has the highest value compared to other indicators. During the Covid-19 pandemic, millennials feel that products unknown to relatives or friends will decrease their purchasing intentions on online travel agents. The covid-19 pandemic will have an impact on people around so millennials will be afraid if relatives do not know the products on the online travel agent. That way, OTA can better market its products to be better known by the public.

6. In the variable psychological risk online, shopping addiction in online travel agents becomes one of the factors feared by millennials compared to other indicators in psychological risk. These risks prevent millennials from using or reducing the use of online travel agents.

7. For further research can use other variable intermediaries such as hotels and aircraft in testing the perception of risk to the intention of online purchases. In addition, researchers can further analyze the influence of pandemics on millennial purchasing behavior after the Covid-19 pandemic.

\section{REFERENCES}

[1] Apjii.or.id. (2018). Asosiasi Penyelenggara Jasa Internet Indonesia. Retrieved January 25, 2020, from

https://apjii.or.id/content/read/104/348/BULETIN AP JII-EDISI-22---Maret-2018
[2] We Are Social. (2020). Digital 2020: Indonesia. Retrieved June 29, 2020

[3] IDN Research Institute. (2019). Indonesia Millennial Report 2019: Memahami Perilaku Millennial Indonesia. http://www.idntimes.com . Retrieved March 2, 2020

[4] Kementrian Pemberdayaan Perempuan dan Perlindungan Anak. 2018. Profil Generasi Milenial Indonesia. Jakarta, Kementerian Pemberdayaan Perempuan dan Perlindungan Anak.

[5] Chang, Y.-W., Hsu, P.-Y. and Yang, Q.-M. (2018), "Integration of online and offline channels: a view of O2O commerce", Internet Research, Vol. 28 No. 4, pp. 926- 945 .

[6] Hult, G.T.M., Sharma, P.N., Morgeson, F.V., III. and Zhang, Y. (2019), "Antecedents and consequences of customer satisfaction: do they differ across online and offline purchases?", Journal of Retailing, Vol. 95 No. 1, pp. 10-23.

[7] Dailysocial.id. (2018). 1.5 juta Transaksi Dalam 24 jam Shopee Mencatat Jumlah Transaksi Tertinggi Di Marketplace E-commerce Indonesia. Retrieved June 25, 2020, from https://dailysocial.id/post/1-5juta-transaksidalam-24-jam-shopee-mencatatjumlah-transaksi-tertinggi-di-marketplaceecommerce-indonesia

[8] Alvara Research Center. 2020. Indonesia Gen Z and Millennial Report 2020: The Battle of Our Generation

[9] Wani, S. N., \& Malik, S. (2013). A comparative study of online shopping behaviour: Effects of perceived risks and benefits. International Journal of Marketing \& Business Communication, 2(4), 41.

[10] Ariffin, Kamalul, S., Mohan, T. and Goh, Y.-N. (2018), "Influence of consumers' perceived risk on consumers' online purchase intention", Journal of Research in Interactive Marketing, Vol. 12 No. 3, pp. 309-327

[11]Hong, W., \& L. Thong, J. Y. (2013). Internet privacy concerns: An integrated conceptualization and four empirical studies. MIS Quarterly, 37(1), 275-298.

[12] Wu, P.C.S., Yeh, G.Y-Y., Hsiao, C-R. (2011). “The effect of store image and service quality on brand image and purchase intention for private label brands", Australasian Marketing Journal, 19: 30-39.

[13]Bhukya, R., \& Singh, S. (2015). The effect of perceived risk dimensions on purchase intention. American Journal of Business, 30(4), 218t230

[14] Cavagnaro, E., Staffieri, S. and Postma, A. (2018), 'Understanding millennials' tourism experience: values and meaning to travel as a key for identifying target clusters for youth (sustainable) 
tourism”, Journal of Tourism Futures, Vol. 4 No. 1, pp. 31-42

[15] Stafford, D. \& Griffis, H. (2008), A Review of Millennial Generation Characteristics and Military Workforce Implications, Center for Naval Analysis, http://www.cna.org/documents/D0018211.A1.pdf, Accessed 8 June 2009

[16] Visit Scotland (2017), "Millennial travelers", January 1, available at:

www.visitscotland.org/binaries/content/ assets/dotorg/pdf/research-papers/millennial-travellers-topicpaper-jan-2017.pdf

[17] U.S. Census Bureau (2013). Annual estimates of the resident population by single year of age and sex for the United States: April 1, 2010 to July 1, 2013.

Retrieved July 14, 2014 from: http://factfinder2.census.gov/faces/tableservices/jsf/ $\mathrm{p}$ ages/ productview.xhtml?src5bkmk.

[18] KPMG (2017), "Meet the millennials", June 1, available at:

https://home.kpmg/content/dam/kpmg/uk/pdf/20 17/04/Meet-the-Millennials-Secured.pdf

[19] Schierz, P.G., Schilke, O. and Wirtz, B.W. (2010), "Understanding consumer acceptance of mobile payment services: an empirical analysis", Electronic Commerce Research and Applications, Vol. 9 No. 3, pp. 209-216.

[20] Park, K.; Reisinger, Y. Differences in the perceived influence of natural disasters and travel risk on international travel. Tour. Geogr. (2010). Vol. 12, pp 1-24

[21] Pandža Bajs, I. (2015), “Tourist perceived value, relationship to satisfaction, and behavioral intentions: the example of the Croatian tourist destination Dubrovnik", Journal of Travel Research, Vol. 54 No. 1, pp. 122-134

[22] Beneke, J., Sousa, S., Mbuyu, M. \& Wickham B, (2016). The Effect of negativr online customer reviews on brand equity and purchase intention of cunsumer electronics in South Africa. The Internasional Review of Retail, Distribution and Consumer Research, 26 (2), 171-201

[23] Jun, S.H. The Effects of Perceived Risk, Brand Credibility and Past Experience on Purchase Intention in the Airbnb Context. Sustainability 2020, 12, 5212.

[24] Ray, S.K. and Sahney, S. (2018), "Indian consumers' risk perception in buying green products: the case of LED light bulbs", Asia Pacific Journal of Marketing and Logistics, Vol. 30 No. 4.

[25] Kaur, S. and Arora, S. (2020), "Role of perceived risk in online banking and its impact on behavioral intention: trust as a moderator", Journal of Asia Business Studies, Vol. ahead-of-print No. ahead-ofprint. https://doi.org/10.1108/JABS-08-2019-0252

[26] Ashoer, Muhammad. (2016). The Impact of Perceived Risk on Consumer Purchase Intention in Indonesia; A Social Commerce Study. Conference: Proceeding of the International Conference on Accounting, Management, Economics and Social Sciences (ICAMESS) - ISBN: 978-602-73705-0-0 